全空気雪冷房システムの温度の制御に関する基礎研究

(全空気方式温度 $\beta$ 制御の場合)

\title{
The Fundamental Study on the Control System of Temperature of All-air Type Snow Air-conditioner (In the Case of All-air Type Temperature Control $\beta$ System)
}

\author{
媚 山 政 良*1.王愛 栄*2 \\ Masayoshi Kobiyama Wang Airong \\ 義 永 秀 樹*3 ・ 等 \\ Hideki Yoshinaga Tatsuya Yamashita \\ 伊 藤 親 臣*5 ・佐々木 賢 知*4 \\ Yoshiomi Ito Masanori Sasaki
}

\begin{abstract}
Energy, food, the environment are basics of the life. The snow can contribute to these many problems to have greatly even if not decisive. The snow/ice as the cold heat source has a remarkable substitute effect for fossil energy as energy. And there is not the discharge of the warm temperature from a system depending for a mechanical refrigerating cycle, and there is an effect for environmental safeguard without using refrigerants such as Freon with this snow air conditioner. In this study, the authors have suggested many systems of the air-conditioner in which the snow is used for cold heat source, and the authors call them all-air type snow air-conditioner and have been analyzing the performance of them. This snow air-conditioner is made by simple construction of a snow storage room, a blower and a dumper for regulation of air flow. The temperature/humidity of the conditioning area is controlled by the mixing hot return air and chilled air from the snow storage room. In this report, the authors discussed on the simplest system among many all air type snow air-conditioning ones. In this system, only the temperature in the air-conditioning area is controlled and this temperature is adjusted by mixing with the circulation hot air through a dumper and the cold air cooled by the snow, and the authors call this system all-air type temperature control $\beta$ system. In this paper, the system is classified into different three models for the analysis, and characteristics of them are investigated analytically and discussed.
\end{abstract}

Keywords : snow air-conditioner, all-air type, control system of temperature, three models, analytical investigation

\section{1.はじめに}

エネルギー, 食糧, 環境は生活の基本である。雪 はこれらの抱える諸問題に決定的ではないにしても 大きく寄与できる。冷熱源としての雪水はエネルギー として化石エネルギーに対し優れた代替効果を有し ている1。たとえば，雪を冷房に用いるならば雪や 熱媒体を移動, 輸送する以外に化石燃料や電力をほ とんど使用しないことから省エネルギーに顕著な効 果が認められ，また，夏場の電力のピーク緩和に役 立つ。さらに, この雪冷房ではフロンなどの冷媒を
使用せず，機械的な冷凍サイクルによるようなシス テムからの温熱の排出がないなど, 環境保全にも効 果がある。

本研究では, 雪を用いた冷房（「雪冷房」と呼ぶ） のシステムの提案を行いその解析を行う。本システ ムは雪の持つ冷熱を空気を用い輸送し冷房を行う形 式であり，そのシステムを「全空気方式雪冷房シス テム」と呼びシステムは貯雪庫, 送風機およびダン パーから成り簡明である。種々ある全空気方式雪冷 房システムのうち導入外気および冷房区域からの循

\footnotetext{
* 1 室蘭工業大学機械システム工学科

* 3 物産不動産(株)

* 5 室蘭工業大学生産情報システム専攻

\section{* 2 上海剣橋通信技術 \\ * 4 三機工業(株)}

[本稿受理：2007年 5 月 22 日, 修正原稿受理：2007年11月16日, 討論期限 : 2008年12月31日]
} 
環空気と貯雪庫からの冷気との混合により所要の温 度，湿度の冷風を作り出すシステム（「 $\alpha \beta$ 制御」と 呼ぶ）については，その概要を既に報告してある ${ }^{2,3)}$ 。 また，暖かい空気を雪に直接接触させ冷風を得る実 験結果 ${ }^{4,5,6)}$ をもとに，システム全体の特性の予測が 可能となり， $\alpha \beta$ 制御の一つ（I 型と呼ぶ）につい て, 外気の温度, 湿度の変化が冷房区域の温湿度環 境に及ぼす基本的な影響を解析的に明らかとし報告 した7)。

本報告においてはいくつかある全空気方式雪冷房 システムのうちでも簡単なシステムで一般の冷房に 対し実用性の高い循環空気の一部を雪により冷やさ れた冷風と混合し, 温度のみの制御を行う方式 (「 $\beta$ 制御」と呼ぶ) について三つの形式に分類し, それらの基本的な特性を解析的に明らかとし検討を 行つたので報告する。

\section{2. $\beta$ 制御による温度制御システム}

冷房区域に冷熱を輸送する方式は種々考えられる が，空気を直接雪に接触させ，冷熱を得，輸送する 全空気方式は, 熱交換器など高度に加 工された機器を利用せずに済み，また， 温度，湿度の制御も容易となり，運用 中に発生する雪に含まれる污濁物質除 去の問題も回避できる。また，空気を 直接雪に接触させることにより, 空気 中の塵埃などの除去も同時に行うこと が可能となり副次的な効果も期待でき $3^{8)}$ 。

外気温湿度の変化, それに伴う熱負 荷の変化が与える冷房区域での設定温 度，湿度への影響を制御するため，全 空気方式雪冷房システムでは，送風機 により風量を制御し熱負荷の変動に対応し, また, 外気，および，循環気の一部を貯雪庫出口の空気に バイパス，混合し温度，湿度を制御をする。外気の バイパス量を $[\alpha][-]$, 循環気のバイパス量を $[\beta]$ とし，これら両方の制御を共に行う場合を $\alpha \beta$ 制御 と呼び, $[\beta]$ のの場合を $\beta$ 制御と呼ぶ。これらの 制御システムは各々特徵を有し, 要求される温度,
湿度の範囲により使い分ける。本報告では，これら の全空気方式雪冷房システムのうちでも簡単で一般 の冷房に対し実用性の高い循環気のバイパス $\beta$ ] 量 を制御する $\beta$ 制御システムについて検討を行う。な お， $\beta$ 制御システムでは冷房区域の温度，あるいは, 湿度のいずれか一方の制御を行うことができるが,

ここでは，一般の冷房を対象とし温度を優先し制御 し，湿度をなり行きとし，これを「温度 $\beta$ 制御」と 呼ぶ。

\section{1 温度 $\beta$ 制御システムの分類}

外気の取り込み位置と循環気のバイパス位置との 関係により，形式 I， II， IIIに分類する。後述する 形式 I の装置全体図を Fig.1 に示す。冷房区域, 機 械室，貯雪庫とからこのシステムは構成されている。 基本的に 1 台の送風機，バイパス風量の調整ダンパー 1 台および単一ダクト系とから成つている。なお, 本報告では，システム各部の熱損失，あるいは，流 体力学的な損出を考慮せず, また, 外気による熱負 荷も簡単なモデルで近似し解析を行い，温度 $\beta$ 制御

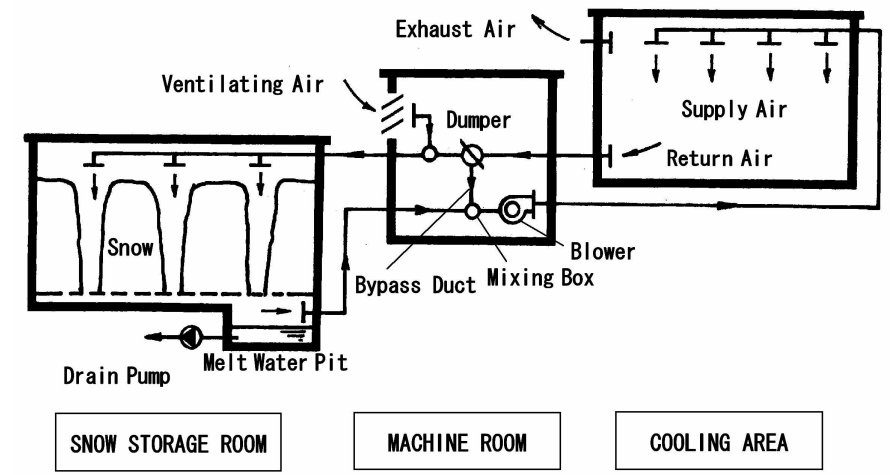

Fig.1 Schematic diagram of temperature control $\beta$ system Model I

の基本的な性質を把握する。

Fig.2 に各形式での機械室内部の構成およびその 周囲のダクトを示す。同図中 [ ] は流量の割合 [-]を 示している。形式 I, II では貯雪庫からみて上流側 で，形式而では下流側で外気をシステムに取り込む。 形式 I では外気の取り込み(3)をバイパス点(2)よりも 下流側，形式I では上流側としている。いずれの形 
式においてもダンパーの入り口(2)に到る暖かい循環 空気のうち $[\beta]$ だけをバイパスし，貯雪庫からの冷 風(4)と(5)あるいは(6)において混合し, 所定の温度の 供給空気（5)あるいは6) を作り冷房区域へ供給す る。なお，形式而の混合器(6においては，混合気内 での霧入りの状態を少なくするため, バイパス空気 (2) と貯雪庫からの冷気(4)の混合を外気との混合より も上流側において行い(6) とする。

換気量を $\left[l_{0}\right]$, 冷房区域出口での風量を $[l]$ とする ときのシステム各部での風量をFig.2 に併記してあ る。たとえば，形式 I では循環気 $[l]$ の内 $[\beta]$ をバイ パスし, 残りの空気 $[l-\beta]$ は外気 $\left[l_{0}\right]$ と混合された 後 $\left[l_{0}+l-\beta\right]$ となり, 貯雪庫へ送られ雪水に開けられ た孔を通し冷却される。また，冷房区域に供給，利 用された空気 $\left[l_{0}+l\right]$ の一部 $\left[l_{0}\right]$ は換気のため屋外へ排 出され，残りの $[l]$ が循環する。

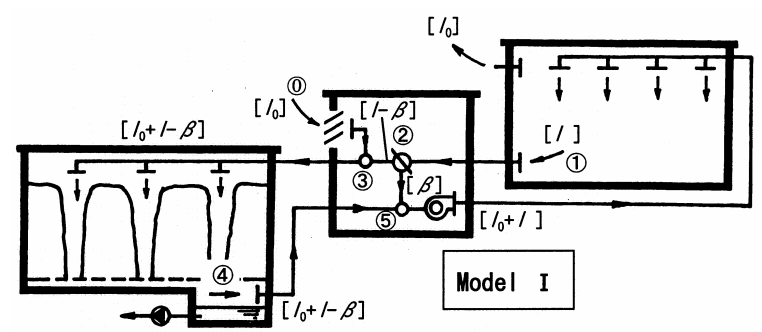

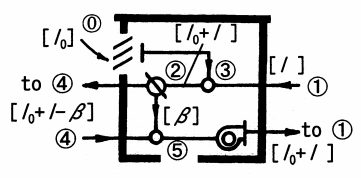

Mode I II

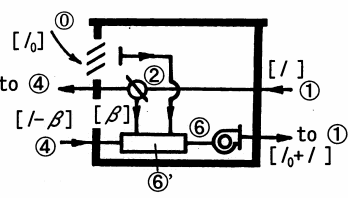

Mode I III

Fig.2 Three models and their constructions and air flow rates

\section{2 雪による空気の冷却システム}

石油や石炭に比較し単位体積当たりのエネルギー 量がかなり少ない雪水を利用する上で，設備全体の 小型化は必須の条件である。このため, 貯雪庫をそ のまま冷風を得る熱交換器として使用する。貯雪庫 内の雪は利用が進むにつれ融解し，形状や表面積が 変化し, 熱交換器としての安定した温度の冷風を得 ることはむずかしい。このため開発した方法が，雪
に開けた多数の垂直の穴を通し冷風を得る方法であつ た ${ }^{4,5,6}$ 。本報告においても貯雪庫内部での熱交換に おいてこの方法を採る。

なお，融解水はポンプにより汲み上げ排出するが, 個別冷房，あるいは，特別な冷房を行う場合に利用 することもできる。

\section{3. 計算式}

冷房区域の所定温度 $t_{1}\left[^{\circ} \mathrm{C}\right]$ を与え, 外気の温度 $t_{0}$, 相対湿度 $\Phi_{0}[\%]$ の変化に伴う冷房区域の相対湿度 $\Phi_{1}$, バイパス量 $\beta$, 冷房区域に送られる冷風の湿 度 $\Phi_{5}$ あるいは $\Phi_{6}$ の変化を計算する。

\section{1 室内冷房負荷モデルと風量}

冷房対象を一般の事務室とする。設計点での室内 冷房負荷を $q_{0}\left[\mathrm{~kJ} / \mathrm{m}^{2} \mathrm{~h}\right]$ とし, その成分 $s\left[\mathrm{~kJ} / \mathrm{m}^{2} \mathrm{~h}\right]$ は次 のように構成されるものとしモデル化する。 なお，各成分の係数は次のように決めた。す なわち，後述の設計点に関する計算条件の下 では，外気（冷房）負荷は $209.3 \mathrm{~kJ} / \mathrm{m}^{2} \mathrm{~h}$ 程度 となる。一方，一般の事務所の外気負荷は， 外気負荷と室内負荷の和として計算される冷 却器負荷 (全冷房負荷) の1/3 程度であるため, 冷却器負荷は $627.9 \mathrm{~kJ} / \mathrm{m}^{2} \mathrm{~h}$ と計算され，また， 室内負荷 $q_{0}$ は $418.6 \mathrm{~kJ} / \mathrm{m}^{2} \mathrm{~h}$ と計算される。室 内負荷は外気の温度変化に依らず一定の室内 発生熱と日射熱, 壁体の通過熱など外気の温 度変化に伴って変化する外部侵入熱とに分け られ，外部侵入熱は壁，空などの構造，立地 条件などを特定し計算しなければならない。

したがって，ここでは，照明，人体，室内機 器の発熱の条件を一般の事務所として得られ る $230.2 \mathrm{~kJ} / \mathrm{m}^{2} \mathrm{~h}$ を室内発生熱とし, 残余の $188.4 \mathrm{~kJ} /$ $\mathrm{m}^{2} \mathrm{~h}$ を外部侵入熱とする。以上の結果を用い, 設計 点での風量（送風機の設計風量に相当）の約 $25 \%$ を しめる換気用空気により運び去る熱量 $s_{0}$ を室内発 生熱の 25/55（室内負荷の 25\%）とし，また，室内 発生熱の残余 $s_{\mathrm{inr}}$ (室内発生熱の $30 / 55$, 室内負荷の 30\%）を室内発生熱のうち換気用空気によらず運び 去る熱量とする。また，外部侵入熱 $S_{\text {od }}($ 設計点にお 
いては室内負荷の 45\%）は室内発生熱搬送に係る 空気以外の空気により運び去るものとし, 式(1)〜 (3)の各係数の值とした。

換気用空気により運び去る室内発生熱量 $s_{0}$

$$
s_{0}=0.25 \times q_{0}
$$

室内発生熱のうち換気用空気によらず運び去る熱 量 $s_{\text {inr }}$

$$
s_{\text {inr }}=0.30 \times q_{0}
$$

室内発生熱に係る空気以外の空気により運び去る 外部侵入熱量 $S_{\mathrm{od}}$

$$
\begin{array}{ll}
S_{\text {od }}=0.45 \times q_{0} \times\left(t_{0}-27\right) /\left(t_{0} \mathrm{dgn}-27\right) & t_{0} \geqq 27 \\
S_{\text {od }}=0 & t_{0}<27
\end{array}
$$

ここで, $t_{0} \mathrm{dgn}\left[{ }^{\circ} \mathrm{C}\right]$ は設計時の外気温度であり, $t_{0}$ は外 気温度である。なお, 外気温度の変化による熱負荷 の変化を式(3)により表されるものとしてある。こ こで, 外気温度が $27^{\circ} \mathrm{C}$ 以下の場合, 外部侵入熱量 $S_{\mathrm{od}}$ は冷房負荷とはみなさないこととしている。設 計点での風量は後述する冷房区域での空気の入口, 出口の温湿度の条件と冷房面積より計算される。こ の設計点での風量に対し各熱量に係わる風量の割合 $l[$-]は次式により表されるものとする。

$$
\begin{aligned}
& l_{0}=S_{0} / q_{0} \\
& l_{\text {inr }}=S_{\text {inr }} / q_{0} \\
& l_{\text {od }}=S_{\text {od }} / q_{0}
\end{aligned}
$$

なお, 解析上, $l$ と $L$ を次のように置く。

$$
\begin{aligned}
& l=l_{\text {inr }}+l_{\text {od }} \\
& L=l+l_{0}
\end{aligned}
$$

\section{$3.2 x_{5}$ あるいは $x_{6}, \beta, x_{1}$ の計算}

湿り空気のエンタルピー $\mathrm{h}[\mathrm{kJ} / \mathrm{kg}(\mathrm{DA})]$ および顕 熱比 $S H F[-]$ は次のように表される。ここで, $x$ は 絶対湿度 $[\mathrm{kg} / \mathrm{kg}(\mathrm{DA})], \quad \mathrm{Cp}$ a $[\mathrm{kJ} / \mathrm{kg}(\mathrm{DA}) \cdot \mathrm{K}], \quad \mathrm{Cp}_{\mathrm{w}}$ $[\mathrm{kJ} / \mathrm{kg} \cdot \mathrm{K}]$ はおのおの空気, 水蒸気の比熱, $r_{0}[\mathrm{~kJ} / \mathrm{kg}]$ は $0{ }^{\circ} \mathrm{C}$ での水の蒸発熱を表す。

$$
h=\mathrm{Cp}_{\mathrm{a}} t+x\left(\mathrm{Cp}_{\mathrm{w}} t+\mathrm{r}_{0}\right)
$$

$$
S H F=\mathrm{Cp}_{\mathrm{a}}\left(t_{1}-t_{5 \text { or } 6}\right) /\left(h_{1}-h_{5 \text { or } 6}\right)
$$

\subsection{1 形式 I}

バイパス空気(2)と貯雪庫からの冷風(4)との混合点 (5)での熱および水蒸気質量の収支より, 次の式を得 る。

$$
\begin{aligned}
& \left(l_{0}+l\right) h_{5}=\beta h_{2}+\left(l_{0}+l-\beta\right) h_{4} \\
& \left(l_{0}+l\right) x_{5}=\beta x_{2}+\left(l_{0}+l-\beta\right) x_{4}
\end{aligned}
$$

式 (11)，(12）において $\beta$ と $x_{5}$ が未知数であり式 （11）に式（9）を代入し, 両式を連立すると $x_{5}$ は次 のように求められ， $\beta$ は式 (14) として求められる。

$$
\begin{gathered}
x_{5}=\frac{\left(h_{4}-\mathrm{Cp}_{\mathrm{a}} t_{5}\right) /\left(h_{2}-h_{4}\right)-x_{4} /\left(x_{2}-x_{4}\right)}{\left(\mathrm{Cp}_{\mathrm{w}} t_{5}+\mathrm{r}_{0}\right) /\left(h_{2}-h_{4}\right)-1 /\left(x_{2}-x_{4}\right)} \\
\beta=\left(l_{0}+l\right)\left[\left(x_{5}-x_{4}\right) /\left(x_{2}-x_{4}\right)\right]
\end{gathered}
$$

ここで, バイパス量 $[\beta]$ が取り得る值の範囲は次の 通りである。なお， $\beta$ の限界を示す $l$ は式 (7)に示 すように外気温度により変化する。

$$
0 \leqq \beta \leqq l
$$

ここで, 冷房区域の出口の湿度 $x_{1}$ は式(10)より導 かれた式(16)により計算される。

$$
x_{1}=\frac{h_{5}-\mathrm{Cp}_{\mathrm{a}} t_{1}+\mathrm{Cp}_{\mathrm{a}}\left(t_{1}-t_{5}\right) / S H F}{\mathrm{Cp}_{\mathrm{w}} t_{1}+\mathrm{r}_{0}}
$$

なお，外気と冷房区域からの空気の混合点(3)での工 ンタルピー $h_{3}$ および絶対湿度 $x_{3}$ は次式により計算 される。

$$
\begin{aligned}
& h_{3}=\left[h_{0} l_{0}+h_{2}(l-\beta)\right] /\left(l_{0}+l-\beta\right) \\
& x_{3}=\left[x_{0} l_{0}+x_{2}(l-\beta)\right] /\left(l_{0}+l-\beta\right)
\end{aligned}
$$

貯雪庫出口(4)の $t$ および $x$ については同入り口(3) との関連を基に後述するが, もし(4)が霧入り空気と なる場合には, 貯雪庫出口にエリミネー夕（気水分 離器）を設置し，これにより霧を機械的に除去する ことを想定し, 位置(4)では, 温度は $t_{4}$ のまま水分 は飽和した状態にあるとする。

システム各部の $t, \Phi, x$ および $\beta$ は上述の式を連 立し解き求められるが，ここでは Gauss-Seidel 法 
による反復計算（式(11)から (18)により求められる 值を逐次代入しつつ同じ計算を繰り返し行う）を行 い連立方程式を解くこととし, 冷房区域の湿度 $x_{1}$ の相続く反復回相互間の相対誤差の絶対值が $10^{-6}$ 以 下をもって解とする。

\subsection{2 形式 II}

バイパス空気(2)と貯雪庫からの冷風(4)との混合点 (5)での熱および水蒸気質量の収支は形式 I と同じく 式(11)，(12)により表される。したがって， $x_{5}, \beta$ は 式(13)，(14)より計算される。また，(5)と(1)を関係 付ける SHF も同じ式(10)により表されるため, 冷 房区域の出口の湿度 $x_{1}$ は式(16)により計算される。

外気と冷房区域からの空気の混合点(3)では形式 I とは流量が違うため, そのエンタルピー $h_{3}$ および 絶対湿度 $x_{3}$ は, 次式により計算される。

$$
\begin{aligned}
& h_{3}=\left(h_{0} l_{0}+h_{1} l\right) /\left(l_{0}+l\right) \\
& x_{3}=\left(x_{0} l_{0}+x_{1} l\right) /\left(l_{0}+l\right)
\end{aligned}
$$

他の諸量の計算式および連立方程式の解法は形式 I と同じである。

\subsection{3 形式 III}

外気，(2)からのバイパス空気と(4)の貯雪庫からの 冷風との混合点(6)での熱および水蒸気質量の収支よ り, 次の式を得る。

$$
\begin{aligned}
& \left(l_{0}+l\right) h_{6}=(l-\beta) h_{4}+\beta h_{2}+l_{0} h_{0} \\
& \left(l_{0}+l\right) x_{6}=(l-\beta) x_{4}+\beta x_{2}+l_{0} x_{0}
\end{aligned}
$$

式(21)，(22)において $\beta$ と $x_{6}$ が未知数であり両式を 連立すると $x_{6}$ は次のように求められ, $\beta$ は式(24) と して求められる。

$$
\begin{gathered}
x_{6}=\frac{\left[l_{0} h_{0}+l h_{4}-\left(l_{0}+l\right) \mathrm{Cp}_{\mathrm{a}} t_{6}\right] /\left(h_{2}-h_{4}\right)-\left(l_{0} x_{0}+l x_{4}\right) /\left(x_{2}-x_{4}\right)}{\left(l_{0}+l\right)\left[\left(\mathrm{Cp}_{\mathrm{w}} t_{6}+\mathrm{r}_{0}\right) /\left(h_{2}-h_{4}\right)-1 /\left(x_{2}-x_{4}\right)\right]} \\
\beta=\left[\left(l_{0}+l\right) x_{6}-\left(l_{0} x_{0}+l x_{4}\right)\right] /\left(x_{2}-x_{4}\right)
\end{gathered}
$$

なお, 混合器6におおいては, 混合気の霧入りの状態 をできるだけ回避するため, バイパス空気(2)と貯雪 庫からの泠気(4)の混合を外気との混合よりも上流側 において行うが, その点を(6) とすると, $h_{6}$ および $x_{6}$ : は次式により計算される。

$$
\begin{aligned}
& h_{6}=\left[\beta h_{2}+(l-\beta) h_{4}\right] / l \\
& x_{6}=\left[\beta x_{2}+(l-\beta) x_{4}\right] / l
\end{aligned}
$$

もし (6)が霧入り空気となる場合には, 混合器出口に エリミネータを設置し，これにより霧を機械的に除去 することを想定し, 位置(6)では, 温度は $t_{6}$ のまま水 分は飽和した状態にあるとする。他の諸量の計算式 および連立方程式の解法は形式 I， II と同じである。

\section{3 貯曹庫出口空気温度 $\boldsymbol{t}_{4}$}

貯雪庫自体を温風を冷やす熱交換器としても使用 する。後述する温度効率 $\eta_{\mathrm{t}}$ が雪の形状の変化には ほとんど影響を受けないようにするため雪の層に鉛 直方向に穴を開け，この穴を通し温風を冷却する方 法を採り, 貯雪庫を熱交換器として利用する上で必 要な貯雪庫入口の温風の温度と出口の冷風の温度と の関係を実験的に明らかとし, 整理した ${ }^{4,5,6)}$ 。ここ では, この実験式を用い, 貯雪庫出口の空気温度 $t_{4}$ を求める。雪の穴の入口温度 $t_{\text {in }}$ と出口温度 $t_{\text {out }}$ の関 係は雪の融解温度を $t_{\text {snow }}\left(=0^{\circ} \mathrm{C}\right)$ とし, 式 $(27)$ によ り定義する温度効率 $\eta_{\mathrm{t}}$ を用いると $\eta_{\mathrm{t}}$ は式 (28) と表 される5)。

$$
\begin{aligned}
\eta_{\mathrm{t}}= & \left(t_{\text {in }}-t_{\text {out }}\right) /\left(t_{\text {in }}-t_{\text {snow }}\right) \\
\eta_{\mathrm{t}}= & \left\{1-0.456\left(30-t_{\text {in }}\right) / 30\right. \\
& \times \exp \left\{-0.94 V_{\mathrm{h}} /\left(0.015 H_{0}+0.024\right)\right\}
\end{aligned}
$$

ここで, $V_{\mathrm{h}}\left[\mathrm{m}^{3} / \mathrm{s}\right]$ は一つの雪の穴を通過する空気流 量であり, $H_{0}[\mathrm{~m}]$ は利用開始時の雪の層の厚さであ る。なお, 整理式(28)は, $H_{0}$ が $2 \mathrm{~m}$ までに関して の結果であるが, 文献 ${ }^{6)}$ に示す $H_{0}$ が $5 \mathrm{~m}$ での結果も 近似できる。雪穴相互間の距離 $D_{0}$ は文献 ${ }^{4,5,6}$ にお けると同様に $1 \mathrm{~m}$ とする。解析においては, $\eta_{\mathrm{t}}$ をコ ンタタクトファクターとし用い, $t_{3}=t_{\mathrm{in}}, t_{4}=t_{\mathrm{out}}$ とす る。また, 貯雪庫出口空気の絶対湿度 $x_{4}$ に関して も $\eta_{\mathrm{t}}$ をコンタタクトファクターとして用いる。

\section{4. 計算条件と結果}

\section{1 計算条件}

設計点での諸量などを次の通りとする。 
[冷房区域] - 一般事務室

- 設定温湿度 : 温度 $t_{1}=27^{\circ} \mathrm{C}, t_{5 \text { or } 6}=17^{\circ} \mathrm{C}$,

$$
\text { 湿度 } \Phi_{1}=40 \%,\left(\Phi_{5 \text { or } 6}=67.7 \%\right)
$$

- 単位面積当たりの冷房負荷 $: q_{0}$

$$
=418.6 \mathrm{~kJ} / \mathrm{m}^{2} \cdot \mathrm{h}
$$

- 顕熱比 : $S H F=1 /(1+0.2)$

·冷房面積 $=1000 \mathrm{~m}^{2}$

[外気] - 温度 : $t_{\mathrm{odgn}}=30^{\circ} \mathrm{C}$

- 湿度 $\Phi_{0 \mathrm{dgn}}=65 \%$

[貯雪庫]

- 冷房時間 514 時間（7～9月，月～金，8時間/日） - 平均冷房負荷率三

[(冷房時間 $\times$ 冷房負荷 $)_{\text {Acutual }}$ ]

[ $(\text { 冷房時間 } \times \text { 冷房負荷 })_{\text {DESIGN }]}=0.4$

・構造, 寸法：貯雪庫は独立した陸

屋根の建物とし, その容量は外部 からの侵入熱9を考慮し, 次の大 きさとする。

高さ $6 \mathrm{~m}$, 幅と奥行き $15 \mathrm{~m}$

貯雪量 $=608 \mathrm{t}$

ただし, 設置場所＝札幌市（気温, 日射量利用)

壁床天井=コンクリート $150 \mathrm{~mm}$

フォームポリスチレン $150 \mathrm{~mm}$

雪の密度 $=0.5 \mathrm{t} / \mathrm{m}^{3}$ 貯雪庫雪充填 率 $=90 \%$ 予備の雪の量 $=$ 侵入熱 および冷房熱量の和の $15 \%$

・運用など：雪の利用開始時での高 さを $H_{0}=5 \mathrm{~m}$ ，また，側壁を通し 外部からの侵入熱に対し $0.5 \mathrm{~m}$ の 雪の層を設け, ピッチ $1 \mathrm{~m}$ で空気 を通す鉛直の穴を設置すると雪に 開ける穴の数は 196 となる。

解析における外気の温湿度の変化 の範囲は次の通りとする。

$$
\begin{aligned}
& 26^{\circ} \mathrm{C} \leqq t_{0} \leqq 34^{\circ} \mathrm{C} \\
& 50 \% \leqq \Phi_{0} \leqq 100 \%
\end{aligned}
$$

なお，設計点での送風機の風量は $26900 \mathrm{~m}^{3} / \mathrm{h}\left([L]=\left[l_{0}+l\right]=1\right.$ の時 $)$ であ
り, 式(29)の条件下で送風機の風量は最大で 43000 $\mathrm{m}^{3} / \mathrm{h}([L]=1.6$ の時 $)$, 最小で $14800 \mathrm{~m}^{3} / \mathrm{h}([L]=0.55$ の 時）となる。なお, 結果において示す貯雪庫を通過 する風量 $\left[L_{\mathrm{pit}}\right]$ は雪の穴を通過する空気の流量に比 例する。

\section{2 計算結果}

形式 I から形式正の結果を Fig.3 に, また, 各形 式での設計点における湿り空気線図上での状態の変 化を Fig.4に示す。

Fig.3において $\left[L_{\mathrm{pit}}\right]$ は形式 I とII では $\left[l_{0}+l-\beta\right]$, 形式IIIでは $[l-\beta]$ を示している。また, 開度（Rate to open）は, ダンパーの開度（分岐流量の割合）を 示し, 100\%は流れの全てがバイパスされ，ダンパー

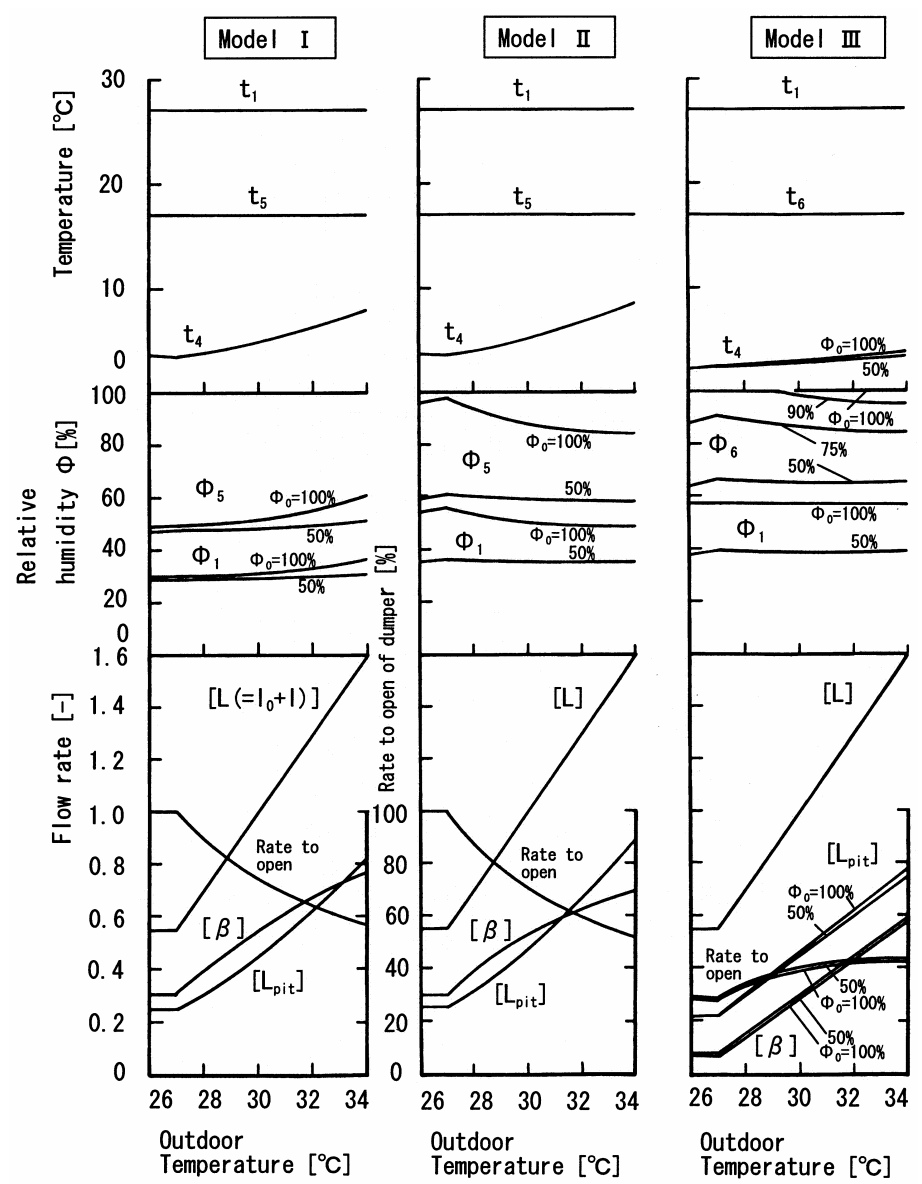

Fig.3 Temperature, humidity and flow rate 
が全開の状態を示している。

冷房区域の入り口温度 $t_{5}$ あるいは $t_{6}$, お よび，出口温度 $t_{1}$ は，いずれの形式にお いても設定した温度を満足している。冷房 負荷のモデル式 (3) において外気による熱 負荷が 0 となる外気温度が $27^{\circ} \mathrm{C}$ 以下におい ても事務所内部の発熱による負荷により設 定温度が達成されている。また，設計点温 度 $30^{\circ} \mathrm{C}$ 以上においても同様であるが，風 量 $[L]$ は増加する。この計算範囲では外気 温度 $34^{\circ} \mathrm{C}$ においても冷房区域の設定温度を 満足するためには，送風機の風量を $[L]=$ 1.6 とする，すなわち風量を設計点におけ るよりも 6 割増やし送風機を設置すること だけにより対応することが可能であること が分かる。

なり行きとした冷房区域の入り湿度 $\Phi_{5}$ あるいは $\Phi_{6}$ は形式によりかなり差異はあ るが，出口湿度 $\Phi_{1}$ には大きな差異はない。 また，いずれの形式においても外気の湿度 $\Phi_{0}$ の影響を受けている。

ダンパーよりも上流側で外気の取り込み を行う形式 II の方が形式 I よりも冷房区域 の湿度は高く, 外気の湿度 $\Phi_{0}$ の影響も大 きく受けているが，本報告の計算範囲内で は，霧入りの状態で冷房区域へ供給される ことはない。なお，形式而では形式 II 以上 に湿度 $\Phi_{0}$ の影響を大きく受け, とくに外 気温度が比較的低く湿度の高い場合，供給 冷風が霧入り状態となる場合があり，混合 器6の出口にはエリミネータを設置する必 要がある。

形式 I および形式Iにおいて，バイパス 量 $[\beta]$ および貯雪庫を通過する風量 $\left[L_{\mathrm{pit}}\right]$ は 外気の湿度 $\Phi_{0}$ の影響をほとんど受けない が形式 III では多少受ける。各形式間での $\left[L_{\mathrm{pit}}\right]$ に大きな差異は認められないが, 形 式 I では，外気は取り込み直後に全量貯雪 庫へ送られるため, 外気への直接的なフィ ルター効果を期待できる。

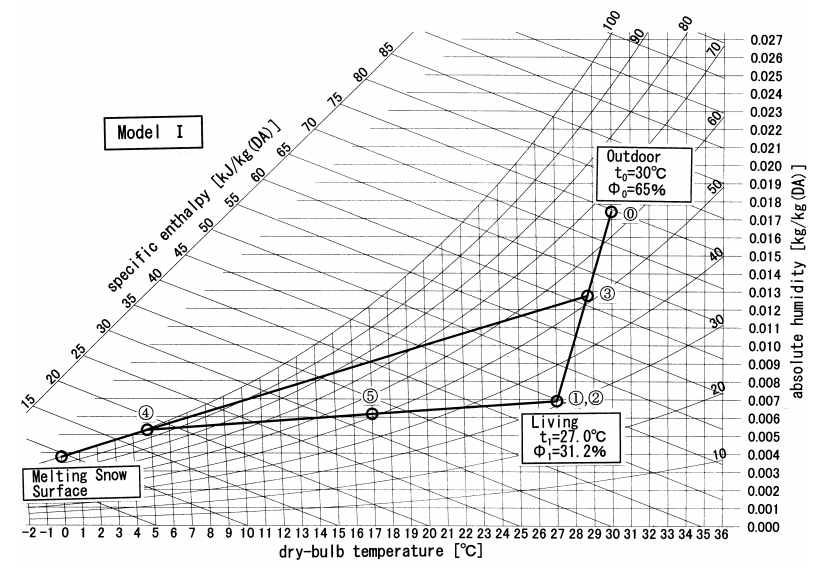

Fig.4 (a) Change of state on psychometric chart of Model I

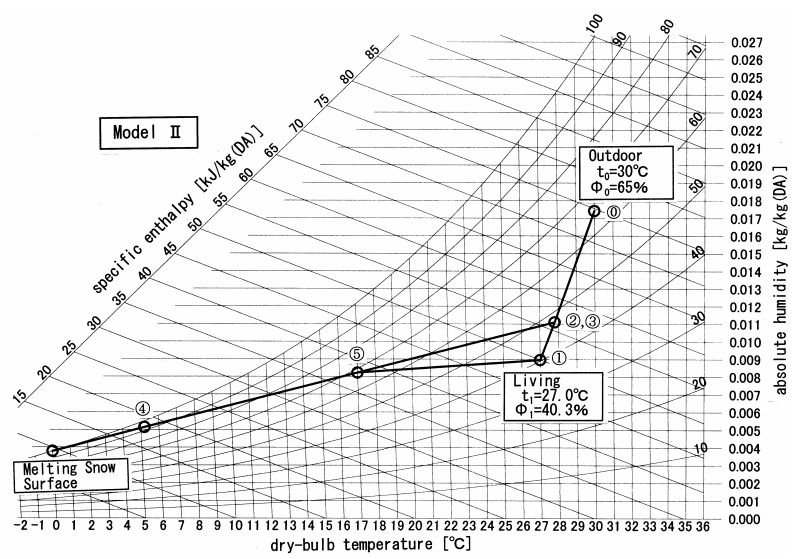

Fig.4 (b) Change of state on psychometric chart of Model II

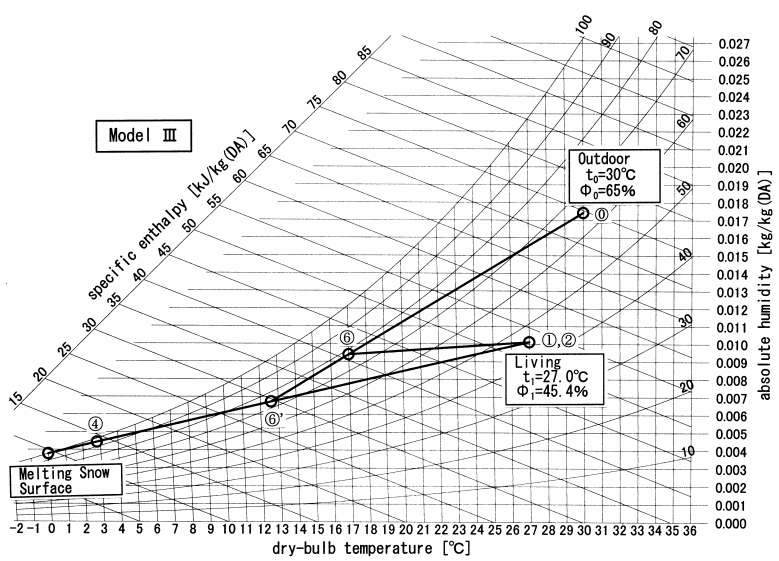

Fig.4 (c) Change of state on psychometric chart of Model III 
なお, 貯雪庫出口温度 $t_{4}$ は貯雪庫を通過する風 量 $\left[L_{\mathrm{pit}}\right]$ により影響を受け， $\left[L_{\mathrm{pit}}\right]$ の大きい形式 I の 方が $t_{4}$ は高い值となっている。

$[\beta]$ の值と $t_{0}$ による変化は形式 I と II とでは似通つ ている。形式IIIでは $[\beta]$ の值は形式 I, 形式Iより も低く, ダンパーの開度の変化は逆であり, また, 開度の変化幅は狭い。流量の変動に対し分岐流量の 割合の変動が鈍感なダンパーがあれば，ダンパーの 開度を固定した運転の可能性が示唆されている。

貯雪庫出口(4)は図 4 からも分かるように設計点に おいても飽和線に近い領域に位置し, 外気温度が低 く, また, 外気の湿度の高い場合には霧入りの状態 となりやすい。このため, いずれの形式においても 貯雪庫の出口にエリミネータを設置する必要のある ことが分かる。

\section{5. まとめ}

本報告においてはいくつかある全空気方式雪冷房 システムのうちでも簡単で一般の冷房に対し実用性 の高い循環空気の一部を雪により冷やされた冷風と 混合し, 温度のみの制御を行う温度 $\beta$ 制御の例につ いて三つの形式に分類し, それらの特性を解析的に 明らかとし検討を行った。得られた主な結果は次の 通りである。

(1) 各形式とも冷房区域での設定温度は達成される。

(2) 設計温度以上の外気温度に対して, 本システ ムは送風機の容量を大きくすることによって対応で きる。

(3)いずれの形式においても貯雪庫出口にエリミ ネータの設置が必要である。

(4) 形式 I では, 冷房区域での湿度は外気の影響 をほとんど受けず，低く安定している。また，他の 形式よりも取り込んだ外気への直接的なフィルター 効果を期待できる。

（5）形式 I では, 冷房区域での湿度は外気の影響 を強く受けるが, 形式 I よりも高い湿度の状態を実 現できる。

（6）形式IIIでは, 形式IIりも冷房区域の湿度は 高く, 混合器の出口にはエリミネータを設置する必 要がある。なお, 同形式ではダンパーの開度を固定
した運転を行いシステムを簡素化できる可能性があ り, また, 貯雪庫を通さず換気のみを行うことがで きる。

(7) 以上の結果より, 形式 I は梅雨期などにおい ても低湿度を維持したい場合に適し, 形式IIは形式 I よりも高い湿度を必要とする場合に適している。 また, 形式而はダンパー開度を固定した運転の可能 性があるとともに, 換気のみの運転を併せ行う, よ り簡素な施設を必要とする場合に適していることが 分かる。

なお，本報告では最小限の機器によりシステムを 構成したが, 送風機を 1 台追加し平衡通風としたり, また，換気の導入にも別個の送風機を用いることに よりシステム全体の圧力差を小さくするとともにシ ステム内での空気の流れの制御を容易とするなどの 工夫は実用上必要である。

本報告では $\beta$ 制御において温度を制御する例につ いて検討を行ったが, 湿度の制御を主とする $\beta$ 制御 システムの構築も重要であり今後解析を行い報告す る予定である。また, 形式正の解析で明らかとなつ た，バイパス量 $[\beta]$ を固定したシステムや換気系を 独立させ，より簡素化した全空気方式雪冷房システ ムについても順次解析し報告を行う予定である。

雪国も夏は暑い。雪を利用すれば雪国こそ快適で ある。

\section{参考文献}

1）媚山政良,「雪資源の石油エネルギー換算と $\mathrm{CO}_{2}$ 低減効果」, 室蘭工業大学紀要第53号, 2002, pp 3-6.

2）媚山政良, 王愛栄, 坂井大樹, 高橋剛, 義永秀 樹, 川本周朗, 松本尚雄, 「全空気方式雪冷房シ ステムでの温度と湿度の制御（ I 型 $\alpha \beta$ 制御の 場合) 」, 寒地環境工学合同シンポジウム講演論 文集, 1994, pp 31-38.

3）媚山政良, 高橋竜一, 川本周朗,「全空気方式雪 冷房システムでの温度と湿度の制御 - 平衡通 風を行う II 型 $\alpha \beta$ 制御一」, 第18回寒地技術シン ポジウム寒地技術論文・報告集, 2002, pp 494495. 
4）王愛栄，媚山政良，飯嶋和明，義永秀樹，杉山 弘,「雪一空気直接熱交換による空気の冷却」, 空気調和・衛生工学会論文集, No.71（1998）, pp 37-42.

5）飯嶋和明，媚山政良，王愛栄，花岡裕，川村昌 彦，「鉛直孔を有する雪塊と空気との熱交換に関 する研究 (空気の流量が冷却能力に及ぼす影響) 」, 日本機械学会論文集 (B編)，65巻636号（1999）, pp 2847-2853.

6）飯嶋和明，媚山政良，王愛栄，花岡裕，伊藤親 臣，「鉛直孔を有する雪塊と空気との熱交換に関 する研究（雪塊の初期高さが冷却能力に及ぼす 影響)」, 日本機械学会論文集 ( $\mathrm{B}$ 編), 65巻641号 (2000), pp 197-202.
7）媚山政良, 王愛栄, 義永秀樹, 飯嶋和明, 伊藤 親臣, 高橋竜一,「全空気雪冷房システムでの温 湿度の制御に関する基礎研究（全空気方式 I 型 $\alpha \beta$ 制御の場合) 」, 日本雪工学会, Vol.24. No.1 (2008), pp12-20.

8）飯嶋和明, 媚山政良, 王愛栄, 小関多賀美, 近 藤昌人, 「雪冷房におけるアンモニアガスの吸収 効果」, 日本機械学会論文集 (B 編), 63巻614号 (1997), pp 3390-3395.

9）媚山政良，「冬期間の自然冷熱エネルギーの利用 に関する研究 (水室型農産物長期保冷庫の開発 と実証実験) 」, 日本機械学会論文集 (B編), 53 巻495号 (1987), pp3358-3362. 